\title{
Tomasz Karpowicz Kultura języka polskiego. Wymowa, ortografia, interpunkcja Wydawnictwo Naukowe PWN, Warszawa 2009, ss. 197
}

Trzeci z serii nowych akademickich podręczników kultury języka polskiego, poświęcony poprawności fonetycznej, ortograficznej oraz interpunkcyjnej wypełnia istniejącą do tej pory lukę wśród językoznawczych opracowań przeznaczonych dla studentów polonistyki i innych kierunków humanistycznych (na przykład studiów neofilologicznych, dziennikarstwa, edytorstwa). Został on pomyślany jako pomoc $\mathrm{w}$ opanowaniu reguł poprawnej wymowy, a także w krytycznym przyswojeniu sobie zasad poprawnego pisania i stosowania znaków przestankowych w zakresie wykraczającym poza zasób wiedzy na ten temat przewidziany w nauczaniu szkolnym.

Kilka lat temu, w roku 2005 Wydawnictwo Naukowe PWN opublikowało podręczniki: Hanny Jadackiej Kultura języka polskiego. Fleksja, słowotwórstwo, składnia oraz Andrzeja Markowskiego Kultura jezzyka polskiego. Teoria. Zagadnienia leksykalne. Stały się one niezbędne, ponieważ cenne i przez długie lata wykorzystywane w dydaktyce uniwersyteckiej podręcznikowe opracowanie Danuty Buttler, Haliny Kurkowskiej i Haliny Satkiewicz ${ }^{1}$, po raz pierwszy wydane na początku lat siedemdziesiątych (t. I) i osiemdziesiątych (t. II), zdążyło już się nieco zdezaktualizować. Niektóre spośród przyjętych tam rozstrzygnięć poprawnościowych nie odpowiadają w pełni sytuacji panującej w języku obecnie. Należało rów-

1 D. Buttler, H. Kurkowska, H. Satkiewicz, Kultura języka polskiego. Zagadnienia poprawności gramatycznej, Warszawa 1971; tychże autorek, Kultura języka polskiego. Zagadnienia poprawności leksykalnej, Warszawa 1982. 
nież wziąć pod uwagę postęp w refleksji teoretycznej dotyczącej zagadnień normatywnych, unowocześnić terminologię oraz przykłady ilustrujące poszczególne zjawiska językowe poddawane ocenie poprawnościowej. Autorki programowo nie uwzględniły wówczas w swoich podręcznikach problemów poprawności fonetycznej, ortograficznej i interpunkcyjnej. W procesie uniwersyteckiego kształcenia polonistów zagadnienia poprawnej wymowy były zwykle, trochę przy okazji, omawiane $\mathrm{w}$ trakcie zajęć z gramatyki opisowej, w części poświęconej fonetyce i fonologii2; co zaś do ortografii i interpunkcji, przyjmowano założenie, że każdy student opanował je w stopniu wystarczającym już wcześniej, w czasie nauki szkolnej. Ich znajomością musiał się między innymi wykazać w części pisemnej egzaminu wstępnego na studia filologiczne. To, jak wiadomo, uległo zmianie. Warto z pewnością poszerzyć wiedzę studentów na temat ortografii i przestankowania. Wobec mody na dowolność pisowni, panującej $\mathrm{w}$ komunikatorach internetowych czy $\mathrm{w}$ komunikacji za pomocą SMS-ów, część studentów trzeba nawet przekonywać do tego, że przestrzeganie zasad ortografii i interpunkcji ma sens, że samo stosowanie tak zwanych "polskich liter": $\ell, q, \dot{z}, \dot{s}, \dot{z}, \dot{c}, \hat{n}, o, t$ jest ważne i potrzebne i że nie należy ich zastępować przez litery bez odpowiednich znaków diakrytycznych. Do pomijania liter ze znakami diakrytycznymi i zastępowania ich odpowiednimi literami bez tych znaków przyczynia się godny pożałowania brak na rynku sprzętu elektronicznego takich klawiatur komputerowych, na których każdej literze polskiego alfabetu odpowiadałby osobny klawisz. Stosowanie klawisza „Alt” znacznie spowalnia proces edycji polskiego tekstu i skłania - zwłaszcza w korespondencji elektronicznej - do pójścia na skróty. Piszący ma nadzieję, że adresat

2 Na przykład podręcznik Bożeny Wierzchowskiej Wymowa polska, Warszawa 1971, przeznaczony - jak sprecyzowała autorka we wstępie - „dla wszystkich, którzy interesują się logopedią", był poświęcony szeroko pojętej fonetyce normatywnej. Wykorzystywany był jednak nie tylko przez logopedów, lecz także przez polonistów, przynajmniej do czasu ukazania się w roku 1980 kolejnego opracowania tej autorki Fonetyka i fonologia języka polskiego, napisanego już wyraźnie z myślą o studentach polonistyki. Aspekt normatywny został w nim uwzględniony w znacznie mniejszym stopniu, marginesowo. Również późniejsze podręczniki fonetyki i fonologii języka polskiego mają charakter zdecydowanie deskryptywny, chociaż w praktyce dość trudno jest oddzielić aspekt czysto opisowy od normatywnego. Skądinąd, nawet określenia wymowa częsta, rzadka, południowo-zachodnia itp. sugerują już podejście normatywne (wariant tradycyjny, ale dziś już rzadko spotykany nie musi być uznany za błędny; zazwyczaj jednak albo już jest poza normą, albo wkrótce zacznie razić większość wykształconych użytkowników języka; warianty rzadkie innowacyjne są z natury rzeczy pozanormatywne; warianty o ograniczonym zasięgu geograficznym w większości wypadków nie wchodzą w skład normy wzorcowej). 
poradzi sobie jakoś z odkodowaniem tekstu. Łatwo jednak o nieporozumienia, bo przy takim traktowaniu pisowni liczba homografów gwałtownie rośnie (np. słowo żebra zamienia się $\mathrm{w}$ słowo zebra, sq̨ $\mathrm{w}$ sad, pqczki w paczki, zaś nazwisko Łoś zyskuje zapis Los). Zdarzają się nieporozumienia, ponieważ kontekst nie zawsze jednoznacznie precyzuje, o co chodzi. $\mathrm{W}$ telefonach komórkowych pisanie $\mathrm{w}$ ten sposób bywa zresztą wymuszone przez brak technicznej możliwości stosowania liter ze znakami diakrytycznymi.

Niepokojące jest również to, że w ocenie społecznej nawet rażące błędy ortograficzne stopniowo przestają być czymś, czego należałoby się wstydzić, czymś świadczącym o brakach w elementarnej wiedzy. Ta sytuacja wymaga uwzględnienia zagadnień ortograficznych $w$ programie zajęć poświęconych kulturze języka w szerszym niż dotychczas zakresie.

Przed ukazaniem się omawianego podręcznika Tomasza Karpowicza, obszerniejszej, usystematyzowanej informacji o zasadach poprawnej wymowy i pisowni student mógł szukać we wstępach do nielicznych słowników wymowy ${ }^{3}$ oraz bardzo licznych słowników ortograficznych ${ }^{4}$, a także w takich opracowaniach, jak Prawidła wymowy polskiej Zenona Klemensiewicza (dwa poziomy normy: wymowa sceniczna i szkolna), Sztuka mówienia Bronisława Wieczorkiewicza (trzy poziomy: wymowa sceniczna, szkolna i potoczna), kolejne wydania Pisowni polskiej PAU, a następnie PAN. Wielką popularnością cieszyły się przez lata, zwłaszcza w nauczaniu szkolnym, wielokrotnie wznawiane Zasady pisowni polskiej $i$ interpunkcji ze słownikiem ortograficznym Stanisława Jodłowskiego i Witolda Taszyckiego. Niektóre popularne poradniki językowe zawierały rozdziały poświęcone ortofonii, rzadziej ortografii, ale wiele $\mathrm{z}$ nich koncentrowało się wyłącznie na poprawności gramatycznej i leksykalnej. Część wiedzy zawartej w tych opracowaniach straciła na aktualności, od-

3 Słownik wymowy polskiej PWN, pod red. Mieczysława Karasia i Marii Madejowej (1977), choć w założeniu nie był pomyślany jako słownik o charakterze zdecydowanie normatywnym (por. Przedmowa M. Karasia), w praktyce wiele wskazówek normatywnych zawiera, zalecając np. wymowę [pensum], nie: [penzum] w części wstępnej (s. XXXIV) i sygnalizując w artykułach hasłowych wymowę, której należy unikać, np. [na'uka] nie: [n'awka]. Wyraźnie normatywny charakter ma napisany przez Aleksandra Zajdę rozdział Problemy wymowy polskiej w ujęciu "Słownika”, zamieszczony w jego części wstępnej. Część ocen normatywnych zawartych $\mathrm{w}$ tym słowniku nie jest już $\mathrm{w}$ pełni aktualna ze względu na czas, który upłynął od jego opracowania.

4 Informacje o współcześnie obowiązującej normie ortograficznej, z uwzględnieniem zmian wprowadzanych przez Radę Języka Polskiego, może student znaleźć w Wielkim Słowniku Ortograficznym PWN pod red. Edwarda Polańskiego. 
nosi się do sytuacji językowej sprzed lat kilkudziesięciu. Tylko zmiany, które zaszły w zasadach interpunkcji, są stosunkowo niewielkie (względnie nowy, bo wprowadzony przez Radę Języka Polskiego pod koniec lat dziewięćdziesiątych, jest nakaz wydzielania w zdaniu przecinkami imiesłowów przysłówkowych także wówczas, gdy nie towarzyszą im żadne określenia) ${ }^{5}$.

Jeśli nie bierzemy pod uwagę specjalistycznych prac logopedycznych lub podręczników wymowy przeznaczonych dla aktorów ani też wybiórczych, szczegółowych zaleceń rozsianych w różnych poradnikach, trudno jest znaleźć opracowania na temat poprawnej wymowy, natomiast w obfitej produkcji wydawniczej dotyczącej ortografii student łatwo może się pogubić. Wartość i użyteczność tych książek (najczęściej niewielkich słowników) jest zresztą bardzo zróżnicowana ${ }^{6}$.

Istniała zatem niekwestionowana potrzeba nowego, akademickiego opracowania wiedzy z dziedziny ortofonii i ortografii, przeznaczonego dla studentów. Książka Tomasza Karpowicza jest odpowiedzią na to zapotrzebowanie. Umożliwi ona nauczycielom akademickim prowadzącym zajęcia z kultury języka dla studentów polonistyki oraz innych kierunków humanistycznych uwzględnienie w programie tych zajęć problematyki ortofonicznej i ortograficznej w szerszym niż dotychczas zakresie, studentom zaś ułatwi dostęp do uporządkowanej wiedzy na te tematy.

Podręcznik składa się z trzech części: I. Wymowa, II. Ortografia i III. Interpunkcja, co jest podziałem narzucającym się w sposób oczywisty. Najobszerniejsza jest część, w której autor omawia zagadnienia poprawności pisowni. Nie dziwi zbytnio czytelnika fakt, że jest ona dwukrotnie dłuższa od części dotyczącej przestankowania, zastanawia natomiast dysproporcja między partią książki poświęconą ortografii i interpunkcji - łącznie 131 stron - a częścią poświęconą ortofonii - tylko 44 strony, z czego na 11 stronach autor omawia problematykę akcentu w języku polskim, należącą do prozodii; na opis zgodnej z normą wymowy głosek i ich grup pozostają zatem 33 strony. W dużym stopniu odzwierciedla to stopień skodyfikowania tych dwóch dziedzin: wymowy i pisowni. $W$ języku pisanym łatwiej jest też egzekwować wielość szczegółowych zale-

5 Słownik interpunkcyjny języka polskiego z zasadami przestankowania Jerzego Podrackiego (Warszawa 1993), choć opracowany przede wszystkim na użytek uczniów, znakomicie służy także studentom.

6 Pisał o tym szerzej Mirosław Bańko w artykule Słowniki ortograficzne w Polsce-fenomen socjologiczny [w:] „Prace Filologiczne” t. XLVIII, Warszawa 2003, s. 7-32. 
ceń, zwłaszcza $\mathrm{w}$ praktyce redakcyjnej, przez poprawnościową kontrolę tekstów przeznaczonych do druku. Wymowa należy do zjawisk $z$ natury rzeczy bardziej żywiołowych niż pisownia. Przeciętny rodzimy użytkownik języka nie uczy się jej w sposób systematyczny ${ }^{7}$, tak jak to się dzieje $\mathrm{z}$ pisownią. Dziecko naśladuje po prostu realizacje foniczne rodziców i innych osób ze swego bezpośredniego otoczenia. Na ostateczny kształt jego indywidualnej wymowy mają też wpływ takie czynniki, jak anatomia narządów mowy, fizjologia, psychika, potrzeby komunikacyjne, miejsce zamieszkania. Próby pełnego ujednolicenia wymowy w wielomilionowej populacji użytkowników dialektu kulturalnego byłyby z góry skazane na niepowodzenie, a może wręcz szkodliwe. Margines swobody użytkownika musi tu być znacznie większy niż w sposobie zapisywania wyrazów. Nie oznacza to, że ta swoboda ma być bezgraniczna: to, co wygodne dla nadawcy wypowiedzi (oszczędzające mu wysiłku), dość łatwo zamienia się w koszmar dla odbiorcy tekstu - słuchacza, ponieważ utrudnia lub nawet całkowicie uniemożliwia mu zrozumienie wysłuchanego komunikatu. Zakłócenia wymowy zwykle też niepotrzebnie skupiają na sobie uwagę odbiorcy, nie pozwalając mu się skoncentrować na treści komunikatu.

Niewielka objętość części podręcznika poświęconej ortofonii tłumaczy się również stanem badań $\mathrm{w}$ zakresie polskiej fonetyki normatywnej. Stosunkowo duże zainteresowanie badaczy wzbudzało dotychczas zjawisko akcentu, a także najnowszy etap ewolucji samogłosek nosowych (tu zwłaszcza prace Marii Madejowej). Inne zjawiska z dziedziny wymowy nie doczekały się jeszcze wszechstronnego opracowania $\mathrm{z}$ normatywnego punktu widzenia. Co do oceny i kwalifikacji poszczególnych typów realizacji fonetycznej opinie językoznawców bywają rozbieżne (por. np. zróżnicowane stanowiska w kwestii synchronicznych i asynchronicznych realizacji zmiękczenia spółgłosek wargowych ${ }^{8}$ ). Trzeba mieć nadzieję, że - w miarę postępu badań - w kolejnych wydaniach podręcznika część poświęcona ortofonii zostanie rozbudowana.

\footnotetext{
7 Naukę ortofonii uwzględnia się $\mathrm{w}$ procesie kształcenia np. aktorów, logopedów i ewentualnie innych grup zawodowych, których praca tego wymaga. Z pewnością korzystne byłoby wprowadzenie nauczania tej problematyki, $\mathrm{w}$ teorii i $\mathrm{w}$ praktyce, $\mathrm{w}$ procesie kształcenia zawodowego nauczycieli wszystkich przedmiotów, a nie tylko nauczycieli języka polskiego.

8 Pisał o tym Bogusław Dunaj (s. 86-87) w artykule O zasadach kodyfikacji wymowy [w:] Kultura języka dziś, pod red. W. Pisarka i H. Zgółkowej, Poznań 1995, s. 83-92.
} 
Kilka niedociągnięć i przemilczeń - czasami drobnych, niekiedy dość istotnych - warto wskazać już teraz. We wstępie do części ortofonicznej podręcznika, zatytułowanym Natura polskiej wymowy, autor używa sformułowań, które (mimowolnie?) sugerują prymat ortografii nad fonetyką:

W polskiej normie fonetycznej znalazły się liczne realizacje potwierdzające odejście od sposobu wymawiania wyrazów zgodnie $\mathrm{z}$ ich zapisem. Istnieją również konteksty, w których wymowa niezgodna $\mathrm{z}$ pisownią nie znajduje akceptacji w społeczeństwie. (s. 15)

Nie można jednak zapominać o tym, że to język pisany jest czymś wtórnym wobec mówionego, nie zaś odwrotnie. Również inne sformułowania użyte $\mathrm{w}$ części wstępnej robią wrażenie niefortunnych, a w najlepszym razie nieścisłych, np.:

Tym bardziej warto więc pamiętać, że spółgłosek czy samogłosek nie można zapisać za pomocą ortografii - służy temu zapis fonetyczny. (s. 20 - po uzasadnieniu potrzeby używania określeń „litery samogłoskowe”, „litery spółgłoskowe" w opisie norm wymowy - A.B.)

Lepiej byłoby przypomnieć studentom, że zapis ortograficzny odwzorowuje wprawdzie głoski (do zapisów tekstów polskich nie używamy przecież ideogramów), lecz robi to w sposób nieprecyzyjny, między innymi dlatego, że zmiany $\mathrm{w}$ ortografii nie nadążają za zmianami w wymowie.

Na stronie 17, wyszczególniając zbiór podstawowych głosek polskich, autor zaznaczył w przypisie, że używa do ich precyzyjnego zapisania alfabetu fonetycznego, zapomniał jednak uściślić już na wstępie, że jest to slawistyczny alfabet fonetyczny ${ }^{9}$. Student polonistyki korzystający $z$ podręcznika odgadnie to $z$ łatwością, jeżeli ma za sobą kurs fonetyki, w czasie którego ten właśnie zapis jest przeważnie używany, ale już studenci innych kierunków filologicznych, przyzwyczajeni w dodatku do korzystania ze słowników dwujęzycznych, opracowanych z zastosowaniem międzynarodowej transkrypcji fonetycznej (IPA), mogą mieć kłopoty z identyfikacją poszczególnych głosek. Notabene w jedynym dotychczas wydanym dużym Słowniku wymowy polskiej PWN z 1977 roku zastosowano właśnie IPA, by ułatwić korzystanie z niego osobom studiującym język

9 Określenie slawistyczny zapis fonetyczny pojawia się dopiero w przypisach do dalszych partii tekstu, np. na s. 49 i na s. 55. 
polski jako obcy. Autor podręcznika miał oczywiście prawo wybrać zapis slawistyczny, najczęściej stosowany w pracach polonistycznych, jednak warto by było od razu na wstępie poinformować o tym czytelnika i wybór ten uzasadnić.

Z kolei decyzja o pominięciu w spisie głosek polskich - spółgłosek

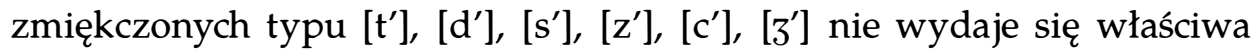
$\mathrm{w}$ opracowaniu normatywnym. Istotnie, głoski te występują w zasadzie tylko w zapożyczeniach (lub w wymowie gwarowej), ale również $\mathrm{i}$ te wyrazy powinny - co oczywiste - być wymawiane poprawnie. Tymczasem rezygnacja $\mathrm{z}$ uwzględnienia spółgłosek tego typu pociąga za sobą brak $\mathrm{w}$ dalszym tekście ostrzeżenia przed niektórymi błędami wymowy: [śinus] zamiast poprawnego [s'inus], [ćissus] zamiast [c'issus] 'roślina pokojowa' itp. Brakuje też $\mathrm{w}$ konsekwencji zwrócenia uwagi na bardzo rozpowszechnione $\mathrm{w}$ młodym pokoleniu realizowanie głosek tylko nieznacznie zmiękczonych zamiast miękkich (prepalatalnych) szczelinowych i zwartoszczelinowych. Bardzo wiele młodych osób, przeważnie płci żeńskiej, choć nie tylko, wita się, mówiąc [čes'c'], kupuje [c'astko] lub wręcz [c"astko] (sic!). Być może autor pominął to zjawisko, traktując je jako problem dla logopedów. Niestety, w młodym pokoleniu przybiera ono rozmiary epidemii i chyba uchodzi nawet za eleganckie. Mówi tak niejedna młoda dziennikarka występująca $\mathrm{w}$ radiu lub $\mathrm{w}$ telewizji, zdarza się to także coraz powszechniej piosenkarkom, sportsmenkom, a nawet aktorkom młodego pokolenia. Każda świeżość zachwalana $\mathrm{w}$ reklamie brzmi [s'f'ežos'c']. Wygląda to raczej na pretensjonalną modę niż typową wadę wymowy, choć trudno ustalić, skąd się wzięła ${ }^{10}$. Taka realizacja fonetyczna wykracza daleko poza normę, jak stwierdza Hanna Jadacka. Osoby popełniające ten błąd zazwyczaj potrafią wymawiać poprawne [ś], [ź], [ć], [ś] itd., kiedy się je do tego zachęci, chociaż utrwalenie dobrego nawyku z pewnością wymaga dłuższych ćwiczeń. Jest to trudne, gdyż w środowisku ludzi młodych rozpowszechniła się akceptacja dla

10 Być może ma to związek z wadami zgryzu wynikającymi ze sztucznego karmienia w niemowlęctwie - tak przypuszcza Ewa Wojnarowska (wypowiedź opublikowana w książce Polszczyzna XX wieku. Ewolucja i perspektywy rozwoju, pod red. S. Dubisza i S. Gajdy, Warszawa 2001, Wystapienia w dyskusji, s. 239-241). Trudno tę hipotezę udowodnić bez statystycznie znaczących badań empirycznych. Zresztą, gdyby taka była rzeczywiście geneza tego zjawiska, powinno by ono występować $\mathrm{w}$ równych proporcjach u osób płci męskiej i żeńskiej. Tak jednak nie jest. U sporej części młodych osób z taką wymową wynika ona prawdopodobnie $\mathrm{z}$ naśladownictwa (jest to wymowa modna) i nieświadomości, że jest to realizacja błędna. 
sepleniącej, półmiękkiej wymowy. Według Hanny Jadackiej, „takie akurat wykolejenia uderzają $\mathrm{w}$ samą istotę (swoistość) polskiego systemu fonetycznego" 11 . Na pewno trzeba o tym przypominać studentom, zwłaszcza studentom kierunków filologicznych. Należy też przy okazji zaznaczyć różnicę funkcjonalną między tym zjawiskiem a kresowym „śledzikowaniem" - częścią odrębnego, regionalnego podsystemu polszczyzny, któremu to zjawisku zawsze towarzyszą inne wyraziste cechy fonetyczne.

W podrozdziale 1.4.1 autor słusznie zwraca uwagę na zróżnicowanie (wielopoziomowość) normy fonetycznej, lecz zapomina odnieść się do dawniej stosowanego rozróżnienia na wymowę sceniczną, szkolną i potoczną, na które student może się natknąć, czytając starsze opracowania (Z. Klemensiewicz, M. Wieczorkiewicz). Przytacza jedynie klasyfikację S. Lubasia i S. Urbańczyka, zaproponowaną we wstępie do zredagowanego przez nich słownika ${ }^{12}$. Autorzy tego niedużego słownika o charakterze popularyzatorskim wskazali sytuacje, w których używa się poszczególnych typów/stylów ${ }^{13}$ wymowy. Tomasz Karpowicz wiąże je jedynie $\mathrm{z}$ tempem mowy: lento (tempo wolne, wymowa wzorcowa) oraz allegro (wymowa szybka, pozanormatywna). Pomiędzy tymi dwoma skrajnościami autor sytuuje wymowę użytkową (niższy poziom normy). W publikacji podręcznikowej na pewno przydałoby się konkretne wyliczenie przykładów sytuacji oficjalnych, półoficjalnych i nieoficjalnych i powiązanie ich z przykładami realizacji fonetycznych im właściwych (najlepiej zilustrowanych nagraniami). Jednoznaczne uzależnienie staranności wymowy od tempa mówienia również nie wydaje się w pełni słuszne. Łatwo wskazać przykłady osób mówiących wolno i zarazem niestarannie lub odwrotnie: dosyć szybko, a mimo to starannie (potrafią tak mówić nie tylko aktorzy).

Można powątpiewać o celowości umieszczania w opisie norm wymowy klasyfikacji upodobnień, zwłaszcza tak zwanych martwych. Nie ma bowiem potrzeby ostrzegania kogokolwiek przed wymową [budka] zamiast [butka]; ten pierwszy wariant nigdy się we współczesnej wymowie nie pojawia. Bardziej logiczne byłoby uwzględnienie tego $\mathrm{w}$ opisie

11 H. Jadacka, Wspótczesne błędy wymawianiowe, „Poradnik Językowy” 2006, z. 10, s. 50.

12 S. Lubaś, S. Urbańczyk, Podręczny słownik wymowy polskiej, Warszawa 1990, s. 8-9. Autorzy ci wyróżniają wymowę bardzo staranną, staranną, potoczną i niestaranną.

$13 \mathrm{Nb}$. używanie tu terminu styl wydaje się niepotrzebnym rozszerzaniem jego znaczenia. 
zjawisk ortograficznych ${ }^{14}$ - i tylko tam - jako wyjaśnienie zapisów typu budka, sprawka, żelazko, w których pojawiają się litery: $d, w, z$ jako odzwierciedlenie w piśmie głosek: [t], [f], [s].

Przy omawianiu tradycyjnych wyjątków od paroksytonezy (typu: fizyka, poszliśmy, osiemset itd.) autor zwraca uwagę na niepotrzebne akcentowanie na trzeciej sylabie od końca takich wyrazów, jak zapożyczony z francuskiego wyraz repertuar, w języku - źródle akcentowany oczywiście na ostatniej sylabie. Stawianie na pierwszym miejscu, a więc uznawanie za wzorowy akcentu proparoksytonicznego w odpowiednim haśle Wielkiego słownika poprawnej polszczyzny: repertuar (dotyczy to tylko formy mianownika) i uznawanie za wariant gorszy, potoczny wymowy repertuar nie jest dobrym rozwiązaniem, jak słusznie dowodzi autor podręcznika. Notabene taką samą wskazówkę poprawnościową znajdujemy w WSPP $\mathrm{w}$ haśle rezerwuar (ale już nie $\mathrm{w}$ hasłach: buduar, peniuar czy trotuar ${ }^{15}$ - akcent proparoksytoniczny nie pojawia się $\mathrm{w}$ nich być może dlatego, że są to wyrazy o jedną sylabę krótsze). Zwyczaj akcentowania tego typu wyrazów na trzeciej sylabie od końca nie ma żadnego historycznego uzasadnienia. Trudno też znaleźć inny powód, by go popierać.

Na odnotowanie zasługuje propozycja, by w obrębie normy wzorcowej wyróżnić podpoziom tradycyjny (s. 49). Na tym podpoziomie sytuuje się, zdaniem autora, wymowa [alg'ebra], [intel'ig'entny], wymawianie wyrazu jabłko z głoską [b] itp. Można by się zastanowić, jakie inne jeszcze warianty wymowy do tego podpoziomu wypadałoby współcześnie zaliczyć. Bywa, że starsi wiekiem użytkownicy polszczyzny kulturalnej jeszcze mówią [pšede fřystk'em] ${ }^{16}$. A czy wymowa przedniojęzykowo-zębowego [ł] to obecnie już tylko element normy regionalnej (wpływy wschodniosłowiańskie), czy jednak wciąż ogólnopolskiej tradycyjnej?

W części poświęconej poprawności pisowni autor proponuje rozdzielenie grupy zjawisk ortograficznych na ortografię szkolną, której znajomość obowiązuje wszystkich użytkowników polszczyzny pisanej, i orto-

14 Tak zresztą autor czyni na s. 64, opisując działanie zasady morfologicznej w ortografii: „Na podstawie pisowni rzeczownika ława wnioskujemy o pisowni jego zdrobnienia ławka, a zatem zgodnie $\mathrm{z}$ relacją słowotwórczą, lecz niezgodnie $\mathrm{z}$ wymową".

$15 \mathrm{~W}$ artykule hasłowym poświęconym temu ostatniemu wyrazowi ostrzega się nawet przed jego akcentowaniem na sylabie trzeciej od końca.

16 WSPP PWN taką wymowę potępia. Notabene WSPP traktuje jako pozanormatywną także wymowę typu [g'eńjuš], chociaż czyni to w sposób nie całkiem konsekwentny. $\mathrm{Na}$ przykład wymowa [intelig'encja], [intelig'entny] zakwalifikowana jest tylko jako przestarzała. 
grafię profesjonalną, niezbędną w pracy korektorów, redaktorów tekstów przeznaczonych do druku i wszelkich osób zawodowo zajmujących się polszczyzną. Do sfery ortografii profesjonalnej zalicza Karpowicz na przykład część szczegółowych zasad dotyczących pisowni łącznej, rozłącznej lub wymagającej użycia dywizu, trudniejsze wypadki stosowania pisowni małą lub wielką literą ${ }^{17}$, zasady dopisywania końcówek fleksyjnych do form odmienianych nazwisk obcych. Jego zdaniem:

Nie chodzi przy tym o to, że licealistom i nieprofesjonalistom wolno błędnie zapisywać przykłady włączone do ortografii profesjonalnej - to nieporozumienie. Chodzi o to, że uczniowie i nieprofesjonaliści, jeśli chcą lub muszą użyć danych przykładów w tekście pisanym, to powinni zdobyć dodatkową wiedzę, nieraz specjalistyczną, na temat ich pisowni, przy czym nieraz odpowiednie przepisy ortograficzne wydadzą im się niezrozumiałe. (s. 61)

Zakres wiedzy ortograficznej przekazywany w nauczaniu szkolnym powinien być dostosowany do potrzeb komunikacyjnych uczniów. Studentom kierunków humanistycznych taki elementarny zasób z pewnością nie wystarczy. W swoim podręczniku Tomasz Karpowicz poświęca zatem najwięcej uwagi ortografii profesjonalnej. Niektóre $z$ poruszonych zagadnień należą przede wszystkim do słowotwórstwa (przedrostki oraz przyrostki) lub fleksji (zakończenia form czasownika), lecz są tu omawiane jako źródła kłopotów ortograficznych.

Wśród zasad ogólnych, na których opiera się polska ortografia, autor słusznie wysuwa na pierwsze miejsce zasadę konwencjonalną; niedostatki w jej opanowaniu zdarzają się nawet wyrobionym autorom i nierzadko umykają uwadze korektorów i redaktorów tekstów prasowych, urzędowych itp., nazbyt czasami polegających na elektronicznych programach edytorskich z funkcją korekty, które wielu błędów nie wychwytują, ponieważ tekstu nie rozumieją. Poprawna jest lub niepoprawna zależnie od znaczenia i od kontekstu - na przykład pisownia $z$ resztq, na raz, jak by, to by; $w$ pót, zawsze niepoprawna *na przeciw. Tej ostatniej komputerowy program również nie skoryguje, ponieważ ma na swojej liście takie wyrazy, jak przyimek na oraz przyimek przeciw, podobnie jak przyimek lub przysłówek naprzeciw. Przykłady można by mnożyć.

17 Warto w tym miejscu odnotować wydany niedawno przez Towarzystwo Miłośników Języka Polskiego, bardzo przydatny Mały słownik użycia wielkich liter w polskich tekstach A. Skudrzyk i K. Urban, Kraków 2009. Nawet duże słowniki ortograficzne nie uwzględniają tej problematyki tak szczegółowo i w tak szerokim zakresie. 
Autor ostrzega przed popełnianiem typowo uczniowskich błędów pisowni, ale i tych zdarzających się często nawet w drukach, np. nieuzasadniona łączna pisownia wyrażeń: *wszechczasów, *wszechwag - tę ostatnią formę, jak zauważa autor podręcznika, sankcjonują nawet słowniki ortograficzne. Tymczasem są to dopełniaczowe formy wyrażeń: wsze 'wszystkie' czasy, wsze wagi. Powinny być pisane oddzielnie, nie istnieją bowiem composita (te) *wszechczasy, (ta) *wszechwaga, chociaż są w polskim zasobie leksykalnym wyrazy typu wszechświat, wszechmoc czy wszechwiedza. Inny typ błędu ortograficznego częsty $\mathrm{w}$ prasie oraz $\mathrm{w}$ tekstach urzędowych to rozłączne pisanie cząstki nie przed rzeczownikami odsłownymi: *nie podpisanie, *nie przystapienie. Takich błędów elektroniczny korektor również nie wskazuje.

Tymczasem w wyobrażeniach "metaortograficznych" przeciętnego Polaka pisownia łączna lub rozłączna czy też stosowanie wielkich liter wydają się czymś mało istotnym. To zakres działania zasady historycznej rozrasta się $\mathrm{w}$ niech do rozmiarów niewiele mających wspólnego z rzeczywistością. Przyczynia się to do nieuzasadnionego przekonania o nadzwyczajnym (i zbędnym) skomplikowaniu polskiej ortografii.

Autor podręcznika pamięta także o zwróceniu uwagi czytelnika na liczne przypadki uzależnienia zapisu wyrazu dużą lub małą literą od tego, w jakim znaczeniu jest użyty, np. Wandal 'nazwa etniczna' i wandal 'niszczyciel, barbarzyńca'. Często nie poprzestaje na podaniu reguły oraz wyjątków od niej, lecz dodatkowo wskazuje na pochodzenie nietypowego zapisu. W nazwach wydarzeń historycznych $\mathrm{w}$ zasadzie nie stosujemy wielkich liter, chyba że wchodzą w ich skład nazwy miejscowe lub osobowe; zapisujemy jednak Wielka Rewolucja Francuska, ponieważ wzorujemy się w tym wypadku na ortografii francuskiej ${ }^{18}$. Ważne i potrzebne są ostrzeżenia przed częstymi ostatnio $\mathrm{w}$ uzusie, lecz nieakceptowanymi przez normę wpływami ortografii angielskiej, na przykład przed zapisywaniem nazw miesięcy i dni tygodnia dużą literą. Zakres fakultatywnego zastosowania pisowni wielką literą został wyczerpująco omówiony. Karpowicz wychwytuje również w kodyfikacji rozstrzygnięcia niekonsekwentne, zdarzające się zwłaszcza w zakresie działania zasady konwen-

18 E. Polański, w artykule Reformy ortografii polskiej - wczoraj, dziś, jutro [w:] „Biuletyn Polskiego Towarzystwa Językoznawczego" t. LX, 2004, s. 29-46, proponuje, by w zapisie nazw wydarzeń historycznych "pozwolić piszącemu na wybór między pisownią bądź wielką literą, bądź małą" (s. 43). 
cjonalnej, takie chociażby jak pisownia wzdłuż łączna, ale bardzo podobnego strukturalnie wyrażenia $w$ poprzek - rozdzielna ${ }^{19}$. Czytelnik znajdzie też w podręczniku informacje na temat pisowni tradycyjnej, obecnie zmodyfikowanej (Allach $\gg$ Allah), pisowni wariantywnej ( $w$ paśmie//w pasmie, nieopodal//nie opodal), a także pisowni nieustabilizowanej (np. wchodząca w skład arabskich nazw osobowych cząstka $\mathrm{Ibn/ibn/Bin/bin).} \mathrm{Przy} \mathrm{tej}$ okazji warto dodać, że również cząstki $d e / / D e, d i / / D i, d u / / D u$ wchodzące w skład wielu nazwisk z pochodzenia romańskich bywają w tekstach polskich pisane czasem wielką a czasem małą literą: Charles De Coster, Cecil De Mille 20, Charles de Gaulle, Michel de Montaigne, Vittorio De Sica, Robert De Niro, Joachim Du Bellay, Roger Martin du Gard, Alfred de Vigny, George de La Tour, Mazo de la Roche// De La Roche, Leonardo DiCaprio. Zależy to od konkretnego nazwiska i od zwyczaju jego zapisywania w kraju i języku ojczystym oznaczanej nim osoby, ale w wielu wypadkach pisownia nazwiska $\mathrm{w}$ tekstach polskich nie wydaje się raz na zawsze ustalona. Dla użytkowników polszczyzny ma to jeszcze tę konsekwencję, że czasami trudno jest szybko znaleźć w słowniku lub encyklopedii jakieś konkretne nazwisko tego typu (de La Tour czy de La Bruyère są umieszczani pod literą L, natomiast Du Bellay czy De Sica pod literą D). Bywa, że nawet $\mathrm{w}$ jednym artykule hasłowym to samo nazwisko jest różnie zapisywane, jeśli chodzi o użycie wielkich liter (por. hasło De Sica w Wielkim słowniku poprawnej polszczyzny PWN, pod red. A. Markowskiego).

$\mathrm{W}$ rozdziale poświęconym interpunkcji autor wyraźnie wskazuje, które z reguł mają charakter obligatoryjny, które zaś fakultatywny. Podobnie jak inni autorzy opracowań dotyczących tej tematyki, kładzie nacisk na składniowy charakter polskiej interpunkcji. Zarówno w części ortograficznej, jak i interpunkcyjnej wprowadza też perspektywę: norma a uzus, w dawniejszych opracowaniach raczej rzadką. Odnotowuje na przykład w uzusie ekspansję przecinków kosztem innych znaków interpunkcyjnych. Jednym z przejawów tego zjawiska jest stosowanie przecinków zamiast średników w rozbudowanych, wieloelementowych wyliczeniach. Autor uznaje to rozwiązanie za "co najwyżej użytkowe”.

19 Por. E. Polański, op. cit., s. 38.

20 W Małym słowniku użycia wielkich liter... (por. przypis 17) znajdujemy zapisy: Charles de Coster, Cecil de Mille, ale Robert De Niro, Vittorio De Sica (bez względu na to, czy zalecane jest użycie dużej czy małej litery w cząstce de, di itp. autorki słownika - chyba słusznie umieszczają tego typu nazwiska pod literą D). 
Ponieważ był to typowy kontekst, w którym znak średnika się pojawiał, może to $\mathrm{z}$ czasem doprowadzić do jego całkowitego zniknięcia z polskiej interpunkcji ${ }^{21}$.

Bardzo pożyteczne w tej części podręcznika jest rozpatrzenie różnych sytuacji, w których dochodzi do zbiegnięcia się dwóch znaków interpunkcyjnych (we wcześniejszych opracowaniach trudno znaleźć informacje na ten temat), zaznajomienie czytelnika $\mathrm{z}$ rozmaitymi rodzajami cudzysłowu i ich zastosowaniami, rozgraniczenie funkcji myślnika od łącznika (dywizu).

Książka Tomasza Karpowicza jest cennym dopełnieniem serii najnowszych podręcznikowych opracowań dotyczących kultury języka polskiego, niezwykle przydatnych w dydaktyce uniwersyteckiej.

Anna Berlińska

Uniwersytet w Białymstoku

21 W Wielkiej Brytanii powstało stowarzyszenie obrońców apostrofu (Apostrophe Protection Society), zanikanie pewnych znaków interpunkcyjnych nie jest więc wyłącznie polskim problemem. 